\title{
ZANCLEAN (EARLY PLIOCENE) SEDIMENT RECORDS OF ICE-SHEET INSTABILITY AT ODP SITE 697 (JANE BASIN), NW WEDDELL SEA, SOUTH ORKNEY MICROCONTINENT
}

FORREST W. LLOYD, Beloit College

Research Advisors: Suzanne O’Connell (Wesleyan University) and Jim Rougvie (Beloit College)

\section{INTRODUCTION}

Accounting for an approximate tenth of the Earth's land surface, Antarctica stores about $70 \%$ of the world's freshwater $\left(29.46\right.$ million $\left.\mathrm{km}^{3}\right)$ in the form of ice which covers $90 \%$ of its continental surface (Fretwell et al. 2013; Kennicut et al., 2014). During climatic transitions, mechanisms related to melting or fracturing destabilize the voluminous Western/ Eastern Antarctic Ice-sheets (WAIS/EAIS) and their freshwater stores are released, further increasing sea-level and destabilizing ice-sheets (Bamber et al., 2013; Favier et al., 2014).

Although complete ice-sheet destabilization is not possible on decadal timescales, sea-level rise affects all peoples, especially those living in coastal poverty, as a $0.8 \mathrm{~m}$ sea-level rise would result in massive rebuilding and relocation efforts for inundated areas (Hallegatte et al., 2013; Hauer et al., 2016). The study and mitigation of WAIS/ EAIS destabilization is further necessitated by increased anthropogenic activity which has accelerated rates of sea-level rise approximately $0.08 \mathrm{~mm}$ annually since 1993 ; melt from glaciers and ice-sheets account for $61 \pm 19 \%$ of this change alone (Gardner et al., 2013; Albrecht and Levermann, 2014; Nerem et al., 2018).

As ice ablation occurs at one of Antarctica's five distinctive crustal regions, glaciers entrain geologic material, transport it seaward, and calve to form iceberg armadas (Bischof, 2001; Boger et al., 2011). Prevailing ocean currents, such as the counterclockwise flowing East Wind Drift (Antarctic Coastal Current), often transport these armadas for several years at an approximate rate of $5 \mathrm{~cm} / \mathrm{s}$ and are the only regional mechanism capable of depositing entrained material as ice-rafted detritus (IRD) thousands of $\mathrm{km}$ from provenance to pelagic depths (Le and Shi, 1997; Diekmann and Kuhn, 1999). The transfer of IRD from a terrestrial source to the oceanic depths can be used to infer sediment provenance, paleo-ocean circulation, paleo-environmental conditions, and possible Heinrich-like Events which reflect glacial/interglacial cycles at high latitudes via iceberg abundance (Heinrich, 1988; Alley and MacAyeal, 1994; Naish et al., 2009; Williams et al., 2010; Passchier; 2017). Although the definition of IRD is subjective, the term is here defined as material $>63 \mu \mathrm{m}$ due to the infrequent ice rafting of silt sized $(<63 \mu \mathrm{m})$ particles (Drewry and Cooper, 1981; Heinrich, 1988; Darby et al., 2002).

By measuring the changes in mean size of sortable silt $(10-63 \mu \mathrm{m})$, a better understanding of the velocity of bottom water can be reached as responses to Pliocene environmental change often result in a change in flow velocity (McCave et al., 1995). In polar regions, where sortable silt from melting ice can be mixed with that transported by bottom currents, changes in sortable silt for bottom currents need to be carefully evaluated (McCave et al, 2013).

The Pliocene epoch (2.58 to 5.33 mya) is characterized by an early and middle warming period and is marked by similarities to those of present and predicted conditions: atmospheric $\mathrm{CO}_{2}$ concentrations ( $\sim 400$ $\mathrm{ppm})$, average surface temperatures $\left(2-3^{\circ} \mathrm{C}\right.$ warmer $)$, and southern landmass configurations (Pagani et al., 2009); therefore, the study of ice-sheet instability during the Pliocene epoch serves as a suitable proxy 
for current and predicted future environmental conditions concerning sea-level rise and ice-loss.

Environmental proxies such as biogenic silica (bSi), ice-rafted detritus (IRD), sortable silt, and XRF elemental counts from Pliocene aged marine sediment cores can be used to better understand responses to environmental change, identify regions of future icesheet instability, and learn more about paleo-ocean circulation conditions at ODP Site 697 (Jane Basin).

\section{METHODS}

Two well-preserved Weddell Sea sediment cores (31X and 32X), from the B-hole of ODP Site 697 (Leg 113), with inter-dispersed IRD intervals were selected from the IODP Gulf Coast Repository (GCR) for XRF, bSi, grain size, and IRD provenance analyses.

Split cores were scraped with a standard glass microscope slide to homogenize surface relief and remove accumulated dust and mold; lithic bodies such as pebbles were removed, measured, and identified. Once prepared, cores were covered with a $4 \mu \mathrm{m}$ SPEX CertiPrep Ultralene film and analyzed using an Avaatech XRF Core Scanner at 10, 30, and $50 \mathrm{kV}$ every $2 \mathrm{~cm}$ to provide quantitative elemental data.

Ten cc sediment aliquots were taken downcore every $10 \mathrm{~cm}$. If a disturbance, such as a crack, was present at the sampling interval a five-cc aliquot was taken; if the region was greatly disturbed it was skipped altogether.

At Wesleyan, approximately $2 \mathrm{~g}$ of sample from 22 separate $(\mathrm{n} 31 \mathrm{X}=3, \mathrm{n} 32 \mathrm{X}=19)$ intervals were prepared for a time-step wet alkaline digestion method modified by the University of Minnesota Limnological Research Center (LCR). Following initial preparation samples were digested in 0.5 molar $\mathrm{NaOH}$ solution and the rate of bSi dissolution was recorded after 60 , 90, 120, 150, and 200-minute intervals; one aliquot was extracted following each digestion. Sample absorption was measured via spectrophotometry and a bSi weight percentages were calculated.

Samples were separated into size fractions for different analyses. $35 \mathrm{~mL}$ of a sodium hexametaphosphate Calgon dispersing agent and a Vortex Genie were used to disaggregate bulk samples, these were later segregated into four grain fractions $(<63 \mu \mathrm{m}, 63-150$ $\mu \mathrm{m}, 150-500 \mu \mathrm{m},>500 \mu \mathrm{m})$ via standard wet-sieving practices. Fractions were dried via heat lamp, weighed with a Mettler AE 240 balance, transferred to a $1 \mathrm{~mL}$ vial; sample percent weights were calculated.

In order to estimate accumulation rates $(>63 \mu \mathrm{m})$ for each core, paleomagnetic reversal stratigraphy from Pudsey et al. (1988) and a geomagnetic polarity timescale by Gee and Kent (2007) were used to estimate absolute ages and linear sedimentation rates (LSR). Due to the lack of age control for Cores $31 \mathrm{X}$ and $32 \mathrm{X}$ the nearest paleomagnetic reversal (Chron $3 \mathrm{~N}-4$ ), located $295.7 \mathrm{mbsf}$ in Core 30X-2, was used to extrapolate ages; since accumulation values are expected to meet or exceed those nearest to sea-level, the linear sedimentation rate (LSR) closest to the top of Core 31X (150 m/my) was applied to the following equation:

Sample Age $=$ Chronological Age $\mathrm{i}_{\mathrm{i}}+\left[\left(\mathrm{Mbsf}_{\text {sample }}-\right.\right.$ Mbsf $\left.\left._{\mathrm{i}}\right) *\left(1 / \mathbf{L S R}_{\text {sample }}\right)\right]$

where $\mathrm{LSR}_{\text {sample }}$ is the linear sedimentation rate (LSR) at the specified sample depth, Mbsf refers to "meters below sea floor," and Chron Age, Mbsf $_{i}(i=$ initial) refer to values at the upper paleomagnetic boundary

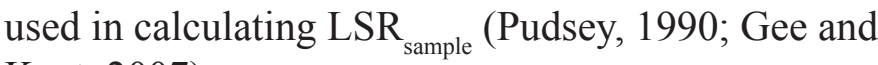
Kent, 2007).

A lithium heteropolytungstate (LST) heavy liquid was used to density separate the $150-500 \mu \mathrm{m}$ sized particles and liquid nitrogen was used to freeze the densest mineral fraction; individual hornblende grains were picked from the resulting heavy fraction for Ar geochronology dating at Columbia University's Lamont-Doherty Earth Observatory. Results from Ar geochronology and Malvern analyses are not available at this time.

\section{RESULTS}

\section{Core Descriptions}

Core $31 \mathrm{X}$ is composed of a highly disturbed siltymud that is dark green to grey in color; evidence of oxidation, sand sized quartz rich material, dropstones, and light banding are found throughout. Geologic material found in $32 \mathrm{X}$ is slightly warmer in color than that of $31 \mathrm{X}$ as it ranges from dark greenish-grey to 
brown, is clay rich, and has sedimentary structures that have been mixed and disturbed by drilling. A highly laminated area is found in 32X-4; pyrite nodules and an abundance of pebble sized igneous drop-stones are found throughout the core (Fig.1).

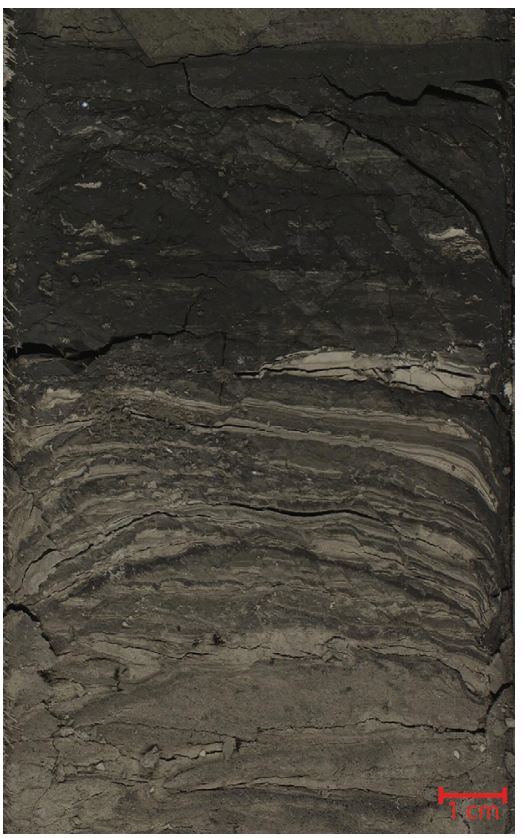

Figure 1. Photo showing variability in core section 32X-4-90-98. Core images, such as this one taken from approximately 317.66 to $317.72 \mathrm{mbsf}$, display a range of colors and particle sizes as found throughout the hole. The light, silt-rich laminae are indicative of contourite deposits which form as a result of contour currents which are turbid and caused by bottom water interaction.

\section{Analysis of XRF spectra}

Downcore trends, based on normalized ratios are highly variable. High ratios of $\mathrm{Fe} / \mathrm{Ti}, \mathrm{Fe} / \mathrm{Al}$, and $\mathrm{S} / \mathrm{Cl}$ signal the presence of anoxic conditions in the core with peaks at 306.6 and $314.72 \mathrm{mbsf}$ (Fig. 2). XRF proxies related to bSi production such as $\mathrm{Si} / \mathrm{Al}$ and $\mathrm{Si} /$ $\mathrm{Ti}$, are found to match trends in $\mathrm{bSi}$ accumulation (Fig. 3).

\section{Accumulation of biogenic silica (bSi)}

The percent composition of bSi tends to increase in sync with increased IRD accumulation (Fig. 4). Biogenic silica averages 1.97 weight percent $(n=22)$ and biosilica ranges from $1.34 \%$ to $7.36 \%$ with a standard deviation of 1.41 . The mean for the three measurements from $31 \mathrm{X}$ is $2.45 \%$ and the standard deviation is 0.525 . Values calculated from Core $32 \mathrm{X}$ $(\mathrm{n}=19)$ range from $1.34 \%$ to $7.36 \%$, have a mean of $2.36 \%$ with a standard deviation of 1.52 .

\section{Grain size analysis}
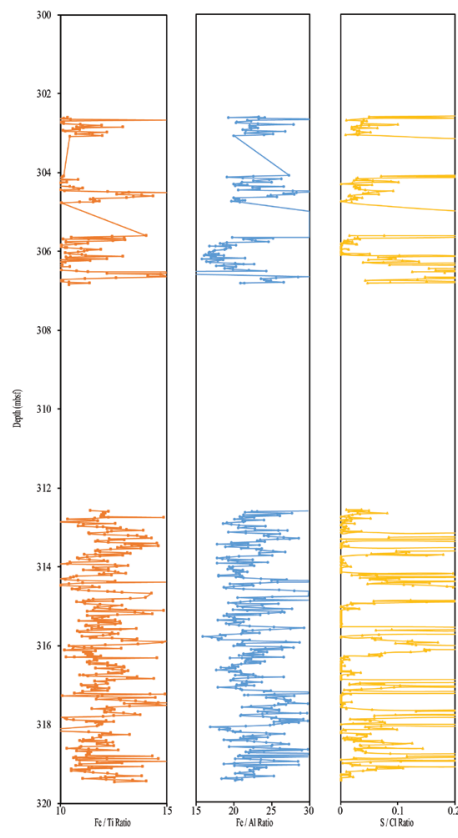

Figure 2. Anoxic pyrite forming conditions in XRF spectra. All $X R F$ proxies for anoxic conditions ( $\mathrm{Fe} / \mathrm{Ti}, \mathrm{Fe} / \mathrm{Al}$, and $\mathrm{S} / \mathrm{Cl}$ ratios) which are necessary for pyrite formation are found peaking at the same depths downhole for Core $31 X$ and Core $32 X$; pyrite is found at these depths.

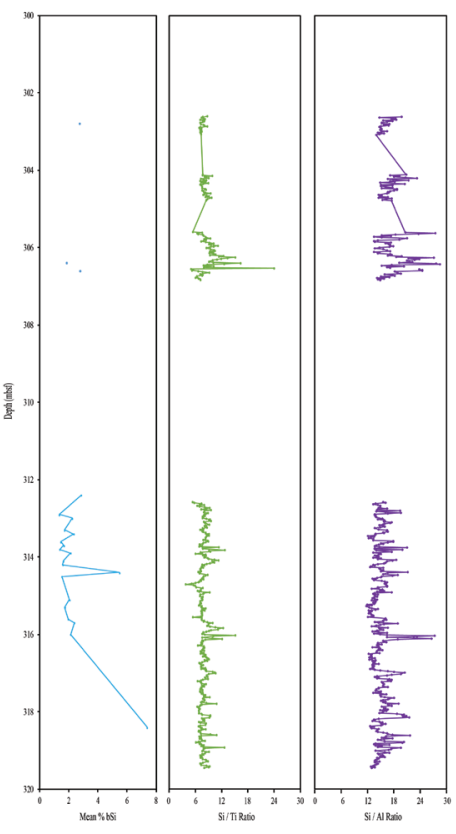

Figure 3. Record of biogenic productivity in XRF spectra. The bSi curve (solid light blue) is plotted downcore with proxies for bSi production; notice that although samples were not taken down the entire hole peaks match and can be used to infer other periods of productivity as they relate to glacial/interglacial periods. 


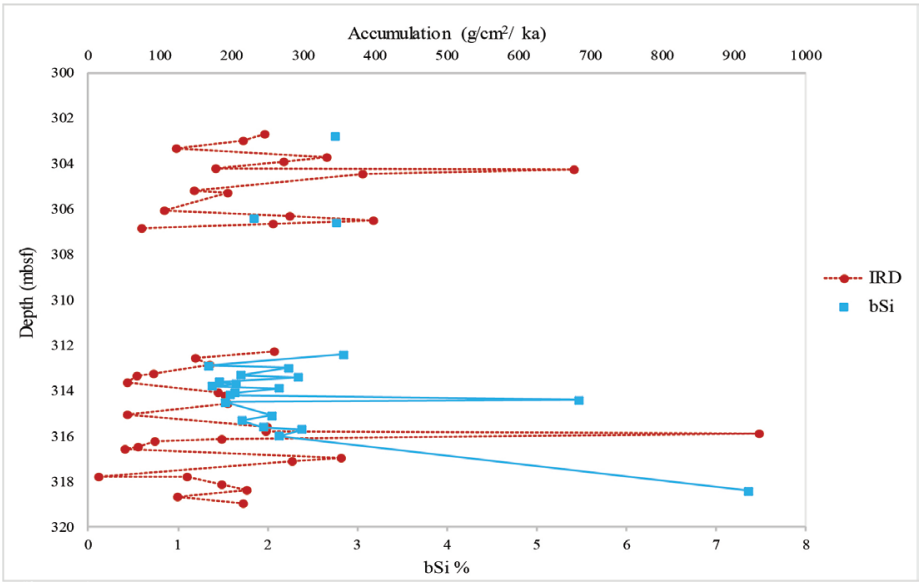

Figure 4. Downhole ice-rafted detritus (IRD) and biogenic silica (bSi) accumulation. Peaks from IRD (dashed red) and bSi accumulation (solid light blue) tend to be synchronous and exhibit similar trends in warming.

Fine particles $(<63 \mu \mathrm{m})$ compose a majority $(\overline{\mathrm{x}}=92.4 \%)$ of the cores while the $>500 \mu \mathrm{m}$ fraction composes the smallest percent of the cores with values ranging from 0.07 to $0.47 \%$. Per sample weight percent values from the $63-150$ fraction $(\overline{\mathrm{x}}=3.42 \%)$ range from $0.44 \%$ to $14.54 \%$ and the slightly smaller $(\overline{\mathrm{x}}=2.94 \%) 150-500 \mu \mathrm{m}$ interval ranges from $0.06 \%$ to $14.91 \%$.

\section{Accumulation of ice-rafted detritus (IRD)}

According to estimates from the paleomagnetic reversal at $4.908 \mathrm{Ma}$ (Chron 3N-4) Cores 31X and 32X together preserve an approximate $108 \mathrm{kyr}$ sediment record spanning the Zanclean age of the Pliocene this assumes LSR has remained unchanged. These cores exhibit downcore variability with abrupt peaks associated with IRD accumulation appearing at $304.3 \mathrm{mbsf}$ (31X) and 315.9 mbsf (32X). Abundant IRD accumulation $\left(\overline{\mathrm{x}}=216.1 \mathrm{~g} / \mathrm{cm}^{2} / \mathrm{ka}\right)$ in these cores range from 14.06 to $934.3 \mathrm{~g} / \mathrm{cm}^{2} / \mathrm{kyr}$. and account for $0.49 \%$ to $32.8 \%$ of the total per sample sediment weight; the median accumulation rate and standard deviation is 185.9 and 170.7 respectively. Core $31 \mathrm{X}$ records approximately 27 kyr of geologic history and has weight percent values ranging from $2.58 \%$ to $23.71 \%$; the mean accumulation rate for $31 \mathrm{X}$ is $258.5 \mathrm{~g} / \mathrm{cm}^{2} / \mathrm{ka}$. Core $32 X$ comprises a majority $(n=25)$ of the total samples $(\mathrm{n}=41)$ and has a high mean sedimentation rate $\left(190.6 \mathrm{~g} / \mathrm{cm}^{2} / \mathrm{ka}\right)$ with values ranging from 14.1 to $934.3 \mathrm{~g} / \mathrm{cm}^{2} / \mathrm{ka}$, a median of 180.8 , and a standard de- viation of 176.5; per sample weight percent values for the core ranged from $0.49 \%$ to $32.8 \%$ with a standard deviation of 6.19 and a median of 6.34 ; the mean per sample weight percent was $6.69 \%$.

\section{DISCUSSION}

Lack of age control for Cores $31 \mathrm{X}$ and $32 \mathrm{X}$ has made correlating depth to age difficult for ODP cores 697B$31 \mathrm{X}$ and $32 \mathrm{X}$ as the only paleomagnetic reversal occurs in Core 30X where the top of Chron 3N-4 (4.980 $\mathrm{Ma}$ ) is identified at $295.7 \mathrm{mbsf}$ (Pudsey, 1990; Gee and Kent, 2007). Assuming a linear sedimentation rate of $150 \mathrm{~m} / \mathrm{my}$ sediment, as accumulation is posited to increase with Jane Basin depth, these cores record an approximate $108 \mathrm{kyrs}(5.03 \mathrm{Ma}$ to $5.13 \mathrm{Ma})$ with the base of Core $32 \mathrm{X}$ aging approximately 16 kyrs older than that of the base of Core $31 \mathrm{X}$.

In conjunction with an abundance of $\mathrm{Si}$ and relative lack of $\mathrm{Ca}$ in Core $31 \mathrm{X}$ and Core $32 \mathrm{X}$, contourite deposits suggest that the site is located at depth, cool, and turbid as laminae is reworked by contour currents to form contourites; larger inter-dispersed dark bands are representative of interglacial cycles as terrigenous material was deposited by icebergs during episodic warming periods (Fig. 1). IRD and bSi peaks suggest that the period recorded by Core $31 \mathrm{X}$ and Core $32 \mathrm{X}$ during the Zanclean age of the Pliocene was relatively warm and underwent a total of 17 interglacial periods, with seven being minor, as evident in Figure 4. Kaufman (2016) focuses on Cores 13X-17X and finds that the mean IRD accumulation rate during the midPliocene warming period was $57.45 \mathrm{~g} / \mathrm{cm}^{2} / \mathrm{kyr}$ with a range between $2.7 \mathrm{~g} / \mathrm{cm}^{2} / \mathrm{kyr}$ to $254 \mathrm{~g} / \mathrm{cm}^{2} / \mathrm{kyr}$. These rates are much lower than those from Cores $31 \mathrm{X}$ and $32 \mathrm{X}$, as values range from $14.06 \mathrm{~g} / \mathrm{cm}^{2} / \mathrm{kyr}$ to 934.3 $\mathrm{g} / \mathrm{cm}^{2} / \mathrm{kyr}$ and average $216.1 \mathrm{~g} / \mathrm{cm}^{2} / \mathrm{kyr}$; such change in accumulation rate may suggest increased ice rafting over the site, a change in provenance, increased entrainment potential of water due to increased discharge, or may reflect an increase in Jane Basin depth. Such data also suggest that the Pliocene is characterized by a series of warming and cooling cycles which began in the Zanclean and culminated in the midPliocene. It should be noted however that when calculating IRD accumulation rates, values are sensitive to reasonable but poorly constrained LSR values $(150 \mathrm{~m} /$ my). 
Despite the presence of data from the early and midPliocene, more data from Cores 18X-30X would be beneficial in discerning when glacially dominated periods were most prevalent as such information could be applied to aid in mitigation efforts, environmental models, and contribute better understanding of environmental conditions at ODP Site 697 during the Pliocene epoch. Unfortunately, poor recovery and disturbed sediment for most of these cores do not make such research likely.

Comparison of $\mathrm{Si} / \mathrm{Al}$ and $\mathrm{Si} / \mathrm{Ti} \mathrm{XRF}$ spectral count ratios in Figure 3 show that local $\mathrm{Si}$ is biogenically sourced, likely from diatom frustules, as bSi accumulation and these XRF spectra align; variance, especially at 316.04 mbsf, can likely be attributed to the deposition of silicates by icebergs (Agnihotri et al., 2008; Dickson et al., 2010). This change in composition may reflect a change in provenance. In conjunction with pyrite occurring at depth, XRF spectral proxies ( $\mathrm{Fe} / \mathrm{Ti}, \mathrm{Fe} / \mathrm{Al}$, and $\mathrm{S} / \mathrm{Cl}$ ratios) follow similar trends suggesting the presence of anoxic conditions or formation of bottom water at this time; such conditions occurred as a result of increased eutrophication following ice-rafted mineral deposition as both conditions reduce abundant oxygen flow (Fig. 2).

\section{FUTURE WORK}

Hornblende age dates $\left({ }^{40} \mathrm{Ar} /{ }^{39} \mathrm{Ar}\right)$ and results from the analysis of fine grains $(<63 \mu \mathrm{m})$ will be used to determine IRD provenance and understand conditions related to bottom water formation during the Pliocene; results will be compared to those of Kaufman (2016) to determine if source regions have changed during this earlier interval.

\section{ACKNOWLEDGEMENTS}

This material is based upon work supported by the Keck Geology Consortium and the National Science Foundation under Grant No. 1659322; further financial support was made possible through the ExxonMobil Corporation. The author would like to thank the International Ocean Discovery ProgramGulf Coast Repository (IODP- GCR), Wesleyan University and Beloit College for allowing access to their instrumentation. Special thanks are extended to Brian LeVay at IODP, Elmo Rawling at the Wisconsin
Geologic \& Natural History Survey, Team Antarctica (Andrew Hollyday, Eduardo Centeno, Eliza Carter, Mark LaPan, Melissa Luna, Noah Spriggs, and Sophia Ptacek), the project directors (Suzanne O'Connell and Joseph Ortiz), and to Jim Rougvie as their collective support and collaboration was pivotal to the project's overall success.

\section{REFERERENCES}

Agnihotri, R., Altabet, M.A., Herbert, T.D., and Tierney, J.E., 2008, Subdecadally resolved paleoceanography of the Peru margin during the last two millennia: Geochemistry, Geophysics, Geosystems, v. 9, p. 1-15.

Albrecht, T., and Levermann, A., 2014, Spontaneous ice-front retreat caused by disintegration of adjacent ice shelf in Antarctica: Earth and Planetary Science Letters, v. 393, p. 26-30.

Alley, R.B., and MacAyeal, D.R., 1994, Ice-rafted debris associated with binge/purge oscillations of the Laurentide Ice Sheet: Paleoceanography, v. 9, p. 503-511.

Bamber, J. L., and Aspinall, W. P., 2013, An expert judgement assessment of future sea level rise from the ice sheets: Nature Climate Change, v. 3, no. 4, p. 424-427.

Bischof, J., 2001, Ice Drift, Ocean Circulation and Climate Change, Heidelberg, Springer.

Boger, S. D., 2011, Antarctica - Before and after Gondwana: Gondwana Research, v. 19, no. 2, p. 335-371.

Darby, D.A., Bischof, J.F., Spielhagen, R.F., Marshall, S.A., and Herman, S.W., 2002, Arctic ice export events and their potential impact on global climate during the late Pleistocene: Paleoceanography, v. 17, p. 15-17.

Dickson, A.J., Leng, M.J., Maslin, M.A., and Röhl, U., 2010, Oceanic, atmospheric and ice-sheet forcing of South East Atlantic Ocean productivity and South African monsoon intensity during MIS12 to 10: Quaternary Science Reviews, v. 29, p. 3936-3947.

Diekmann, B., and Kuhn, G., 1999, Provenance and dispersal of glacial-marine surface sediments in the Weddell Sea and adjoining areas, Antarctica: ice-rafting versus current transport: Marine Geology, v. 158, no. 1-4, p. 209-231. 
Drewry, D. J., and Cooper, A. P. R., 1981, Processes and Models of Antarctic glaciomarine sedimentation: Annals of Glaciology, v. 2, p. 117122.

Favier, L., Durand, G., Cornford, S.L., Gudmundsson, G.H., Gagliardini, O., Gillet-Chaulet, F., Zwinger, T., Payne, A.J., and Brocq, A.M.L., 2014, Retreat of Pine Island Glacier controlled by marine icesheet instability: Nature Climate Change, v. 4, p. 117-121.

Fretwell, P., Pritchard, H. D., Vaughan, D. G., Bamber, J. L., Barrand, N. E., Bell, R., Bianchi, C., Bingham, R. G., Blankenship, D. D., Casassa, G., Catania, G., Callens, D., Conway, H., Cook,. J., Corr, H. F. J., Damaske, D., Damm, V., Ferraccioli, F.,Forsberg, R., Fujita, S., Gim, Y., Gogineni, P., Griggs, J. A., Hindmarsh, R. C. A., Holmlund, P., Holt, J. W., Jacobel, R. W., Jenkins, A., Jokat, W., Jordan, T., King, E. C., Kohler, J., Krabill, W., Riger-Kusk, M., Langley, K. A., Leitchenkov, G., Leuschen, C., Luyendyk, B. P., Matsuoka, K., Mouginot, J., Nitsche, F. O., Nogi, Y., Nost, O. A., Popov, S. V., Rignot, E., Rippin, D. M., Rivera, A., Roberts, J., Ross, N., Siegert, M. J., Smith, A. M., Steinhage, D., Studinger, M., Sun, B., Tinto, B. K.,Welch, B. C., Wilson, D., Young, D. A., Xiangbin, C., and Zirizzotti, A., 2013, Bedmap2: improved ice bed, surface and thickness datasets for Antarctica: Cryosphere, v. 7, no. 1, p. 375-393.

Gardner, A. S., Moholdt, G., Cogley, J. G., Wouters, B., Arendt, A. A., Wahr, J., Berthier, E., Hock, R., Pfeffer, W. T., Kaser, G., Ligtenberg, S. R. M., Bolch, T., Sharp, M. J., Hagen, J. O., van den Broeke, M. R., and Paul, F., 2013, A Reconciled Estimate of Glacier Contributions to Sea Level Rise: 2003 to 2009: Science, v. 340, no. 6134, p. 852-857.

Gee, J.S., and Kent, D.V., 2007, Source of Oceanic Magnetic Anomalies and the Geomagnetic Polarity Timescale: Treatise on Geophysics, v. 5, p. 419-460.

Hallegatte, S., Green, C., Nicholls, R.J., and CorfeeMorlot, J., 2013, Future flood losses in major coastal cities: Nature Climate Change, v. 3, p. 802-806.
Hauer, M.E., Evans, J.M., and Mishra, D.R., 2016, Millions projected to be at risk from sea-level rise in the continental United States: Nature Climate Change, v. 6, p. 691-695.

Heinrich, H., 1988, Origin and Consequences of Cyclic Ice Rafting in the Northeast Atlantic Ocean During the Past 130,000 Years: Quaternary Research, v. 29, p. 142-152.

Kaufman, Z.S., 2016, Sediment Interpretations of Ice Rafted Debris in the Weddell Sea, Antarctica: a 3-3.8 mya Record from ODP Site 697 [thesis]: Wesleyan University.

Kennicutt, M.C., Chown, S.L., Cassano, J.J., Liggett, D., Massom, R., Peck, L.S., Rintoul, S.R., Storey, J.W.V., Vaughan, D.G., Wilson, T.J., and Sutherland, W.J., 2014, Polar research: Six priorities for Antarctic science, v. 512, p. 23-25.

Le, K., and Shi, J., 1997, A study of circulation and mixing in the region of Prydz Bay, Antarctica: Studia Marina Sinica, v. 38, p. 39-52.

McCave, I.N., Crowhurst, S.J., Kuhn, G., Hillenbrand, C.-D., and Meredith, M.P., 2013, Minimal change in Antarctic Circumpolar Current flow speed between the last glacial and Holocene: Nature Geoscience, v. 7, p. 113-116.

McCave, I.N., Manighetti, B., and Robinson, S.G., 1995, Sortable silt and fine sediment size/ composition slicing: Parameters for palaeocurrent speed and palaeoceanography: Paleoceanography, v. 10, p. 593-610.

Naish, T., Powell, R., Levy, R., Wilson, G., Scherer, R., Talarico, F., Krissek, L.,Niessen, F., Pompilio, M., Wilson, T., Carter, L., DeConto, R., Huybers, P., McKay, R., Pollard, D., Ross, J., Winter, D., Barrett, P., Browne, G., Cody, R., Cowan, E., Crampton, J., Dunbar, G., Dunbar, N., Florindo, F., Gebhardt, C., Graham, I., Hannah, M., Hansaraj, D., Harwood, D., Helling, D., Henrys, S., Hinnov, L., Kuhn, G., Kyle, P., Laufer, A., Maffioli, P., Magens, D., Mandernack, K., McIntosh, W., Millan, C., Morin, R., Ohneiser, C., Paulsen, T., Persico, D., Raine, I., Reed, J., Riesselman, C., Sagnotti, L., Schmitt, D., Sjunneskog, C., Strong, P., Taviani, M., Vogel, S., Wilch, T., and Williams, T., 2009, Obliquitypaced Pliocene West Antarctic ice sheet oscillations: Nature, v. 458, no. 7236, p. 322U384. 
Nerem, R.S., Beckley, B.D., Fasullo, J.T., Hamlington, B.D., Masters, D., and Mitchum, G.T., 2018, Climate-change-driven accelerated sea-level rise detected in the altimeter era: Proceedings of the National Academy of Sciences, v. 115, p. 2022-2025.

Pagani, M., Liu, Z., Lariviere, J., and Ravelo, A.C., 2009, High Earth-system climate sensitivity determined from Pliocene carbon dioxide concentrations: Nature Geoscience, v. 3, p. 27-30.

Passchier, S., Ciarletta, D., Miriagos, T., Bijl, P., Bohaty, S., 2017. An Antarctic stratigraphic record of step-wise ice growth through the Eocene-Oligocene Transition. Geological Society of America Bulletin, Vol. 129.

Pudsey, C. J. "Grain size and diatom content of hemipelagic sediments at Site 697, ODP Leg 113: A record of Pliocene-Pleistocene climate. "Proceedings of the Ocean Drilling Program, Scientific Results. Vol.113. 1990.

Pudsey, C.J., Barker, P.F., and Hamilton, N., 1988, Weddell Sea abyssal sediments a record of Antarctic Bottom Water Flow: Marine Geology, v. 81, p. 289-314.

Williams, T., et al. "Evidence for iceberg armadas from East Antarctica in the Southern Ocean during the late Miocene and early Pliocene." Earth and Planetary Science Letters 290.3 (2010): 351-361. 